\title{
Sargent and Proust: An Elusive Mouvance
}

\author{
Emily Eells and Stephen Coon
}

Whether John Singer Sargent and Marcel Proust ever met is unknown, but they shared close personal relationships and moved in the same circles. Among those relationships were artists Paul Helleu and Jacques-Émile Blanche; society figures Dr Samuel Pozzi, Comte Robert de Montesquiou and Winnaretta Singer; and musicians Gabriel Fauré, Léon Delafosse and Reynaldo Hahn. The works of the painter and the novelist share other traits: penetrating and incisive portraiture; encyclopedic portrayals of social transformation; and complex representations of outsiders in Jewish, homosexual and artistic figures. Sargent and Proust are unexpected counterparts in the representation of life in the Belle Époque.

Keywords: John Singer Sargent, Marcel Proust, Dr Samuel Pozzi, Paul Helleu, Jacques-Émile Blanche, Léon Delafosse, Gabriel Fauré, Winnaretta Singer

John Singer Sargent's In the Luxembourg Gardens (1879) has been used more than once as the cover illustration of English translations of Marcel Proust's $\grave{A}$ la recherche $d u$ temps perdu. It materializes the affinity between the American painter and the French writer fifteen years his junior, picturing Odette Swann, the woman whom Proust's narrator nicknames 'the lady in pink', on an evening stroll with her husband or lover. More recently, the French publisher Livre de poche reissued Proust's novel in eight volumes with works by Sargent reproduced on the covers. On the cover of the first volume, Du côté de chez Swann, the cropping of Mrs Arthur Knowles and Her Two Sons (1902) cuts out the figure of the younger boy on the left, just as Proust omits his younger brother Robert from his autobiographical narrative, jealously keeping all the mother's affection for the young narrator. The cover of La Prisonnière (Madame Paul Poirson, 1885) evokes sensuality by drawing attention to the cuirass bodice of the dress which, reproduced as a detail without the elaborate collar above, could be mistaken for a corset and is thus in keeping with the intimacy of the love affair narrated in that volume. That sense of intimacy is prolonged in the choice of cover for the following volume, Albertine disparue - (Sargent's Repose - Nonchaloire, 1911), which focuses on the narrator's lover pictured in a state of abandonment foreshadowing her death. The intervening volumes are illustrated respectively using Lady Helen Vincent (1904) for Un amour de Swann, Two White Dresses (1911) for À l'ombre des jeunes filles en fleurs, Mrs William George Raphael (1906) for Le Côté de Guermantes and John Ridgeley Carter (1901) for Sodome et Gomorrhe. For the final volume, the publisher chose a close-up from Théobald Chartran's portrait of Charles Haas (1891), one of the models for Proust's Charles Swann. A more consistent choice would have been Sargent's portrait of George Washington Vanderbilt (1890), a bibliophile 
and heir to a fortune, which he invested in his library. His penetrating dark eyes, his 'gesture of mannered elegance ${ }^{1}$ and even the slight angle of his pose all bear an uncanny resemblance to Proust. Perhaps identifying Proust so closely with a portrait would have made too bold a statement about Sargent and Proust's elusive relationship. Although they might be affiliated both artistically and socially, there is no proof that they actually met and only slight evidence of Proust's knowledge of Sargent's work.

The series of covers chosen by the publisher Livre de poche poses the question of the exact relationship and possible affinities between Proust and Sargent. As Sargent appears not to have owned any of Proust's books or even to have heard of him, this article will concentrate on what Proust knew and said about Sargent, establishing the facts before exploring the complex network of intersecting relationships linking the painter and the novelist and their works.

Proust makes no mention of Sargent in his printed work and no reference to any of his paintings in his novel. He does, however, name Sargent a few times in his correspondence and once, in passing, in an unpublished manuscript belonging to the series of pastiches he wrote in 1908 and 1909. Proust practised writing pastiches imitating various writers' styles before embarking on his multi-volumed novel $\grave{A}$ la recherche du temps perdu. His series of pastiches known as L'Affaire Lemoine were inspired by the real-life scandal involving Henri Lemoine, who claimed he could manufacture diamonds from coal and even convinced the De Beers diamond mine to invest in the scheme.

Proust retells the story of the counterfeit diamond in counterfeit literary style. In the case of his pastiche of Ruskin, he proposes to transpose the Lemoine story into a series of frescoes allegedly by Giotto and scripts a guided tour of them purportedly by the author of Giotto and his Works in Padua. Proust mocks the way Ruskin digresses and his random association of names. He gives the pastiche its sting by omitting the focal point of the narrative, stressing that Giotto did not paint the diamond. It is at this point that Sargent is mentioned:

'You're thinking that if Giotto did not paint the diamond, it's because he couldn't paint it, that he wasn't skilled enough for that. Believe me, Giotto was as skilled in representing absolutely anything as $\mathrm{Mr}$ Lerolle or $\mathrm{Mr}$ Sargent, and if he did not paint the diamond, it's because he did not want to paint it'. ${ }^{2}$ Proust has Ruskin associate Sargent with the French painter Henry Lerolle (1848-1929), lampooning the way the critic compares established masters with second-rate artists. Lerolle is perhaps best known for The Organ Rehearsal (1885), ${ }^{3}$ an accomplished depiction of music in the making that appears stilted when compared with the dynamic audacity of Sargent's Rehearsal of the Pasdeloup Orchestra at the Cirque d'hiver (circa 1879-80). ${ }^{4}$ Sargent's black-and-white colour scheme is suggestive of a musical score, where the brush strokes seem to trace sound waves on the canvas.

Proust's pastiche shows that Sargent's name was in circulation in France at the time but provides no proof of what Proust knew about him or his work. There is, however, concrete evidence that some five 
years after writing the pastiche, Proust saw one of Sargent's paintings, Dr Pozzi at Home, painted in 1881, and on display in the Pozzi residence until the sale of the doctor's art collection in 1919 (Figure 1 ). ${ }^{5}$ Pozzi was a friend of Proust's family and, like both Proust's father and brother, he was a doctor: Proust's brother Robert even worked as Pozzi's assistant. Pozzi specialized in gynaecology, with a particular interest in hermaphroditism and sexual anomalies. He was an excellent diagnostician, a leading surgeon and professor of medicine, nicknamed Dr God by his lover Sarah Bernhardt. Proust was inspired by Pozzi to endow his fictitious character Dr Cottard with the same qualities and nickname: Proust has Mme Verdurin say of one of her guests: 'I don't call him Dr Cottard, I call him Dr God!' ${ }^{\prime}$ A lady's man, Pozzi was famous for his numerous love affairs, which Sargent conveys in the portrait, which exudes sexual energy, picturing the doctor toying with the cord of his belt, as if to signal that he is about to undo it. His elongated fingers are conspicuous, perhaps as a reminder that he is known to have invented the technique of bimanual examination of the ovaries. The title of the portrait specifies that Dr Pozzi is at home: it portrays him in the intimacy of his domestic setting, clad in a sumptuous red dressing gown, over a bright white shirt trimmed with frilly collar and cuffs. He is standing in front of a curtain that hints at his covert activities.

Proust saw the portrait at Pozzi's home in November 1914, as is clear from the letter he wrote to the doctor following his visit:

Dear Sir, Even though this sort of compliment is not very pleasing when addressed from man to man - but a writer must forget that he has a sex and must speak for all -, the other day I would have liked to say that of all the works of art I saw in your home the other day, the one I most admired was ... yourself! While you were showing me the marvellous Sargent portrait, and apologising for the lack of resemblance with the model today, I did not dare tell you, because of the same feeling of embarrassment I mentioned above, that you are, at this point in time, better. In purely aesthetic terms, I think that the silver scattered over your beard (and thanks to the softness which that tonality adds to your face) is a kind of make-up which is more flattering than Sargent's red. Comparing the two figures, I preferred the second. ${ }^{7}$

Proust is barely able to dissimulate his attraction to the charismatic doctor, and calls on his asexual status as a writer to cover his embarrassment. He evokes the passing of time, reflecting on the thirty-three years which have elapsed since Sargent painted portrait of Pozzi at the age of thirty-five. As in the concluding volume of his novel, when Proust has the narrator meet up with people he had known after a lapse of many years, he uses the verb 'grimer' ${ }^{8}$ in his letter - meaning to be masked with make-up - to indicate that time has changed one's appearance. He speaks of sixty-eight-year-old Pozzi as a work of art, where 'tonality' and shades of silver are used to capture the doctor's presence.

A few days later, Proust sent a second letter to Pozzi in an attempt to rewrite his initial flattery, claiming it was objective and aesthetic, and not the expression of infatuation: 'My aesthetic appreciation was completely sincere and, as our enemies would say, "objective". The "snapshot" that I've kept from that last visit seems to me to be tinged with a sense of 
Figure 1. John Singer Sargent, Dr Pozzi at Home.

The Armand Hammer

Collection, Gift of the

Armand Hammer

Foundation. Hammer

Museum, Los Angeles.

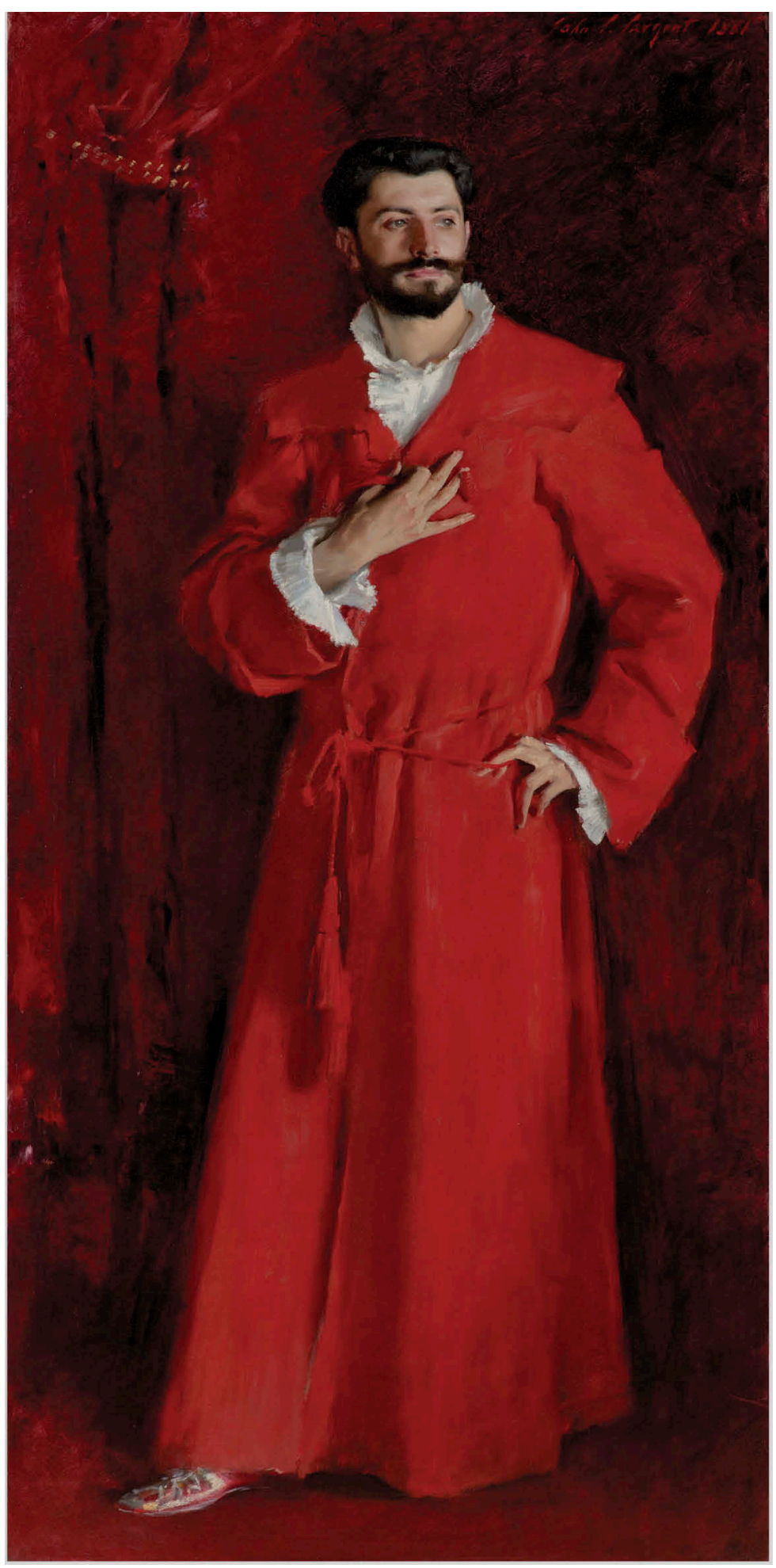


seduction which is even greater than those of older images stored intact in my memory. It's merely the impression of an artist: only women would be able to say if it's accurate' .9 Clearly the image imprinted on Proust's mind's eye was mediated through Sargent's portrait with its theatrical pose and strikingly flamboyant use of red, and the tantalizing touch of exoticism in the oriental slipper sticking out from under the robe.

Apart from the portrait of Pozzi, Proust never refers, or even alludes, to any other works by Sargent. Even though we cannot prove direct influence, we can measure the plausibility that Proust knew more works by Sargent than the doctor's portrait. We can also explore the circumstances that might have led to an encounter between them, though we have no record that they ever met. This speculation is based on the intuition that Proust and Sargent had more in common than can be charted: their works echo with fin de siècle aestheticism, and Sargent's presence as an eminent 'cultural passeur'10 on the Parisian cultural scene is imprinted on Proust's novel À la recherche du temps perdu.

As Proust knew Pozzi over such a long period of time - 'toujours' [forever] ${ }^{11}$ to use his word - it is possible that he saw two other works by Sargent belonging to the doctor's collection: ${ }^{12}$ Mme Gautreau Drinking $a$ Toast (circa 1883) and the watercolour version of Fumée D'Ambre Gris called Incensing the Veil (c. 1880) (Figures 2 and 3). ${ }^{13}$ Both would have been of interest to him: the first as a close-up of Madame Gautreau in a kind of snapshot capturing a moment of social exchange in an intimate setting, and the second as a visual representation of synaesthesia conveying smell through a modulation of the shades of white. Sargent's depiction of an interior with reflected artificial light parallels Proust's own representations of similar scenes and his attention to lighting. This portrait of Madame Gautreau is compounded with a homosexual subtext if we follow the argument that underneath it lies the face of Albert Belleroche, Sargent's model, protégé, and fellow painter. ${ }^{14}$ That instance of blurring sexual boundaries by superposing them would have fascinated Proust if he had known about the similarities between the two superimposable portraits.

Proust and Sargent moved in intersecting networks of cosmopolitan artists and writers who provided the former with second-hand knowledge of the latter's work. Concentric circles revolved around Robert de Montesquiou, author of a review of Sargent's work: they included Jacques-Émile Blanche and Paul Helleu, who were both friends of Proust and were also friends of Sargent, who painted them.

Jacques-Émile Blanche, who in 1892 painted a portrait of Proust wearing an orchid in his lapel, has been called 'the French Sargent' ${ }^{15}$ Sargent met his French counterpart no later than 1886, when he painted a portrait of Blanche in his garden in Auteuil - located, coincidentally, next to the home of Proust's grandfather. We can only wonder whether the fifteenyear-old Proust wandered across to his neighbours when Sargent was there painting. Although Sargent had inscribed the painting 'à mon ami Blanche', their relationship soured, and the Frenchman reported that 
Figure 2. John Singer Sargent, Madame Gautreau Drinking a Toast, Isabella Stewart Gardner Museum, Boston.

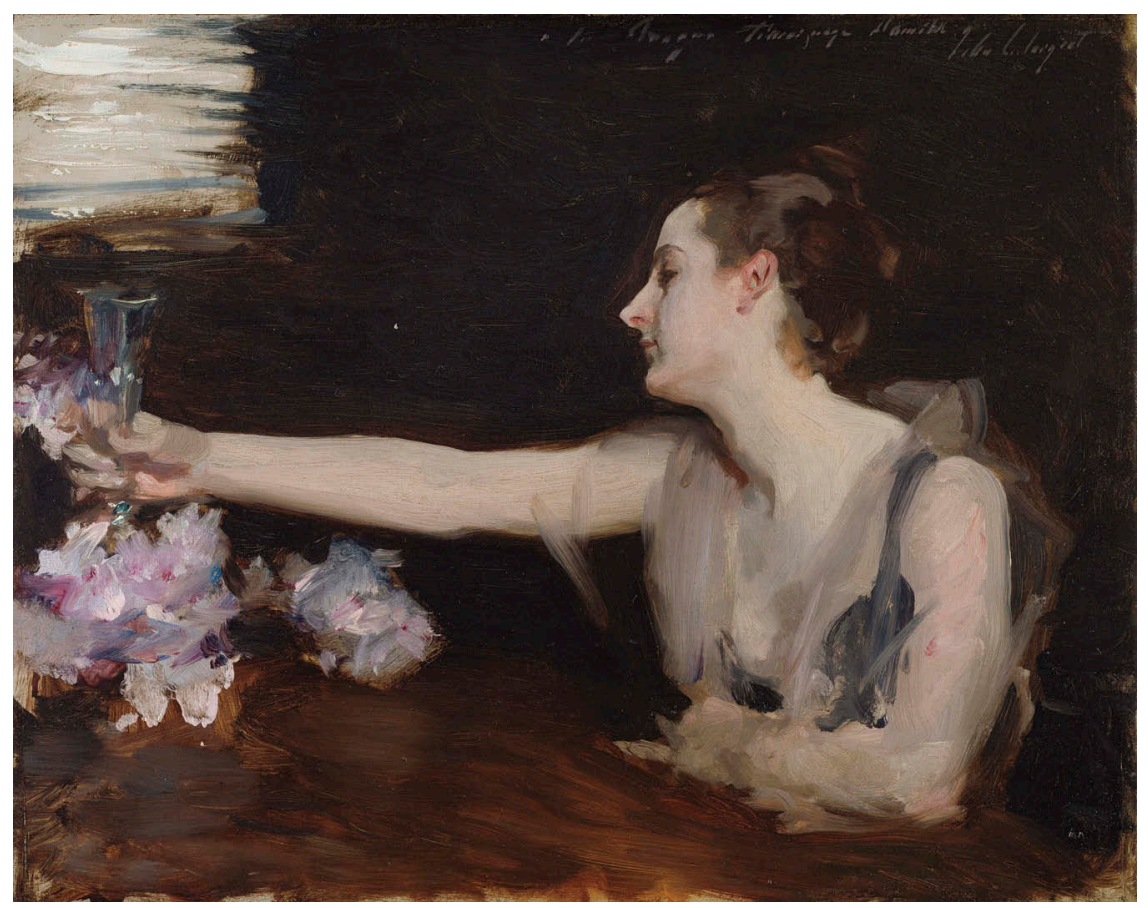

'Sargent had active associations with men'16 and started the rumour that Sargent's sex life was notorious in Paris and Venice. Blanche maligns him as 'a frenzied bugger,' ${ }^{17}$ a claim that has never been independently confirmed, although it has been said that in Venice, Sargent only had eyes for the gondoliers. ${ }^{18}$

Proust's exchanges with Montesquiou - a close friend of Pozzi's reveal that he had some indirect knowledge of Sargent's work. Proust corresponded with Montesquiou at the time the latter published a review of Alice Meynell's volume on Sargent. Entitled 'Le Pavé Rouge', the review appeared in Les Arts de la vie in 1905 where, just a few months earlier, Proust had published his translation of Ruskin's Sesame and Lilies. The conjunction of the Ruskin translation and the article on Sargent in the same journal might explain why Proust grouped their names together in the pastiche he wrote three years later. Montesquiou's article appeared in the wake of an exhibition of Sargent's work held at the Grand Palais between mid-April and the end of June 1905, which Proust explains he had not seen because of the strange hours he kept (it closed at the time he got up): 'As for Sargent, as the exhibit closes at nightfall, I did not see any of it'.

Proust goes on to comment on Montesquiou's scathing review of Meynell's large, illustrated volume of Sargent's work: 'But what you say could apply to all art (which is what makes it so highly significant). And concerning what is personal to Sargent, we know everything because you 
Figure 3. John Singer

Sargent, Incensing the Veil. Isabella Stewart Gardner Museum, Boston.

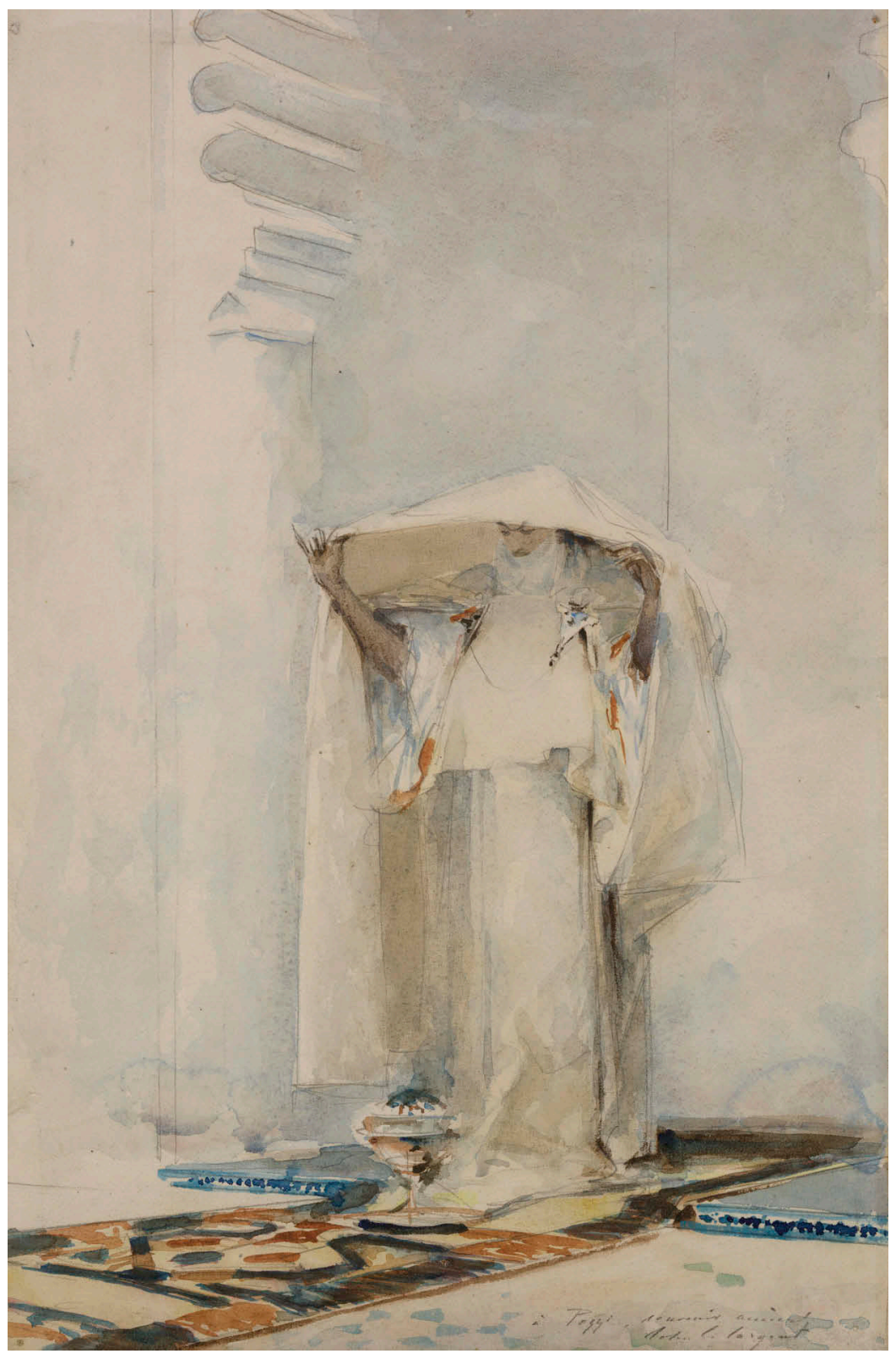

show us everything, because you draw each work again and make a better painting of it'. ${ }^{19}$ It is not clear what in the review prompted him to comment that Montesquiou's points can be related to all art, unless it is a reference to aestheticism as expressed by the critic's ekphrasis of Sargent's Lady with the Rose (Charlotte Louise Burckhardt, 1882): 
It was a pretty young lady, lacking in character, in a black damask, bell-shaped dress, under which the young painter's fearsome skill was already threatening. In her right hand, if I remember correctly ... the model is holding a rose without any leaves, one of those small tea-roses from which the painter had already made one of those flowers executed with such mastery that they prompt the enthusiastic amateur to exclaim: 'They are no longer roses!'20

Is Proust mocking the philistine's wonder at the aesthetic alchemy that transforms a real object into a work of art?

As it is unclear whether Proust more than skim-read Montesquiou's review, his concluding praise of the way Montesquiou paints with words sounds like empty, false flattery. Judging from the one painting which captivated him several years later, Proust cannot have agreed with Montesquiou's critical remarks about Sargent: 'There was also a portrait of our learned friend, Dr Pozzi, which remained in the shadows, and for good reason. The painter had, we don't know why, dressed him all in red (like the paving-stone) and, for yet another unknown reason, had endowed him with a false air of a Valois of Gynaecology'. ${ }^{21}$

'Le Pavé Rouge' triggered an exchange with Blanche about Sargent's An Interior in Venice (1898) which would have at least acquainted Proust with the subject of the painting, even if he never saw it reproduced himself (Figure 4). Blanche objects to Montesquiou's following exclamation criticizing the interior decoration: 'My goodness, the furniture in this Venetian Interior is so hideous! It must be the Montecuculli Palace, rebuilt by the Princess Edmond de Polignac! Unless the Countess René de Béarn also has a pied-à-terre in Venice'.$^{22}$ Montesquiou thus mistakes it for a depiction of the Venetian residence of the Princess of Polignac or the Countess of Béarn, which Jacques-Émile Blanche corrects, asserting that the drawing room Sargent painted was in fact on the upper floors of Palazzo Barbaro, belonging to the Bostonian couple Mr and Mrs Curtis, who hosted gatherings of expatriate Anglo-American artists and writers. When Blanche asks Proust to act as a go-between and to tell Montesquiou that he was wrong, he was as acerbic towards the reviewer as the reviewer had been towards the artist:

Please tell Robert that the interior Sargent painted in Venice, which is perfectly admirable and without blemish, belongs to Mr Curtis senior and is not what he describes as one of Mme de Polignac's arrangements.

A judge who is so harsh must be faultless, at least with the information he imparts. Which he is not, having only ever seen, with clarity, the niellos decorating a trinket, and fly droppings everywhere else. ${ }^{23}$

Proust's only comment relating to Sargent's An Interior in Venice has nothing to do with the painting itself, but with the interior decoration of the palaces Montesquiou mistakenly thought it might represent. ${ }^{24}$ Montesquiou's dismissal of the painting is countered by Blanche's eloquent ekphrasis published after Proust's death. It is possible that Proust and his portraitist discussed the painting informally and that he had some insight into Blanche's assessment of it:

I would rate above all the group portraits a canvas of just a few square centimetres to which Sargent might not have ascribed as high a value as that which it has gained over the years. It depicts a scene in Venice. The sala of the piano nobile in one of the ancient palazzi on the 
Figure 4. John Singer Sargent, An Interior in Venice Royal Academy of Arts, London; photographer: Prudence Cuming Associates Limited.

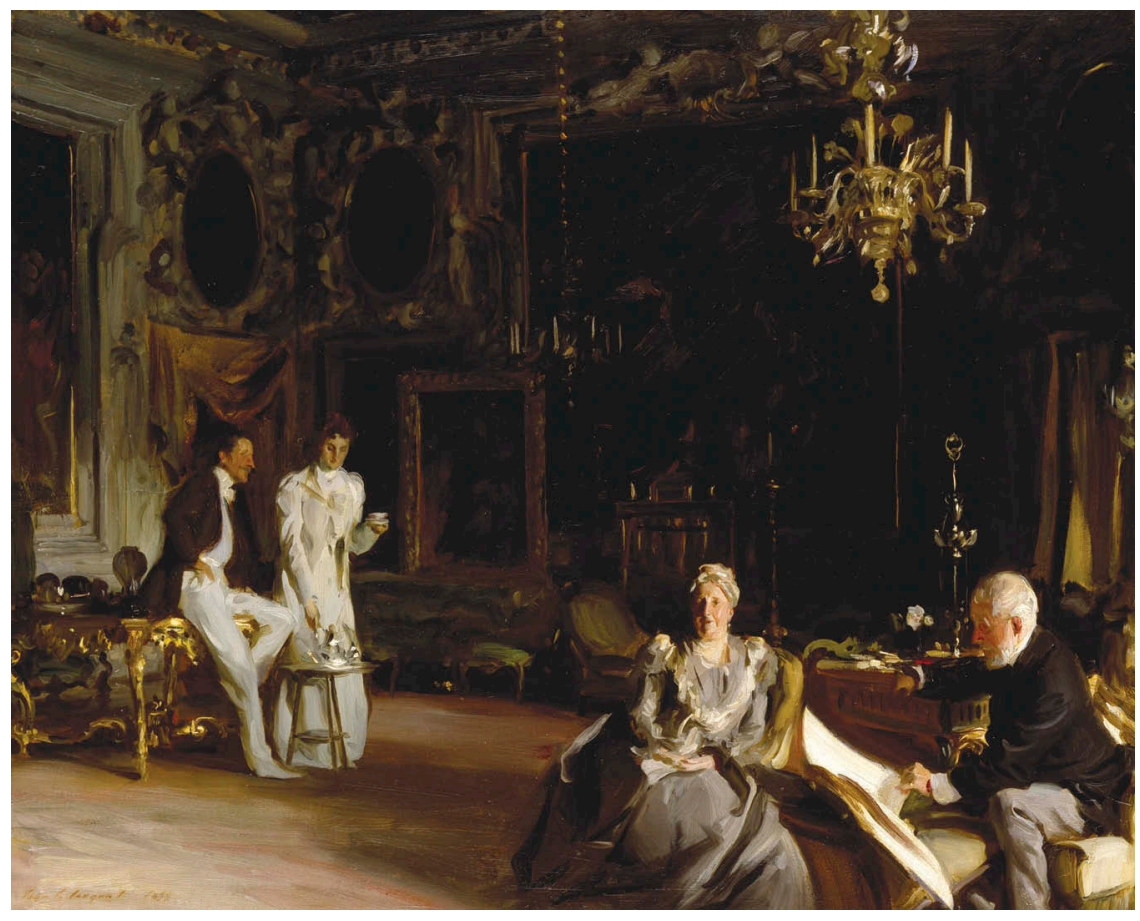

Grand Canal. It's an afternoon in August: the sun is beating down on the undulating tiled floor, buckling from the sagging of the piles driven into the mud bearing the weight of tons of marble. This salon with its vaulted, stucco ceiling painted in fresco, high and vast like some of the chambers in the Doges' Palace, belongs to two lovely elderly people, $\mathrm{Mr}$ and Mrs Curtis, who are permanent residents in Venice and the most senior members of the American community there. Sargent, who was their guest in the summer, has them pose in the foreground, highlighted, each in their customary chair, surrounded by the beautiful objects they had collected in Italy and others they had brought from England and Boston. These two serene figures in voluntary exile are bathed in the soft light from the sea-sky and the canal, far from the skyscrapers, the tramways, the automobile horns, the train whistles, and progress. One day, their coffins will be carried by boat to the cemetery, to the sound of oars cutting through the veined jade of the lagoon, and their funeral will mark the passing of a Europeanized American aristocracy, the death of a high society life and of noble leisure. The novels of Henry James will reveal their secrets to future Yankees manufacturing airplane motors. The son and daughter-in-law of the old Curtis couple - the dashing generation of the Riviera - are standing in the back of the sala, poised for a cruise to India or Japan. This young married couple, who have a pied-à-terre in Paris, a villa near MonteCarlo and a chalet in Deauville, seem to be verifying a trouser crease or the cut of a skirt designed by Redfern, before going to the Lido for afternoon tea or to hunt for bric-a-brac. Sargent has painted a poignant picture of the social manners of this idle, uprooted group: they represented his natural milieu. ${ }^{25}$

Had Proust seen the painting, he would have recognized that Sargent's representation of time passing and the demise of an era brought about by the advent of modern life was consonant with his own work.

Proust includes Paul Helleu in the cluster of artists he associated with Sargent and through him he might have seen one of the several paintings 
Sargent did of his friend from the École des Beaux-Arts in Paris. Proust met Helleu through Robert de Montesquiou and spent time with him in the summers of 1907 and 1912 in Cabourg, the principal model for his fictional resort of Balbec. Helleu served as one of the models for Elstir, a composite character based on several different artists, including Sargent. Proust adds Helleu's name next to Sargent's in his pastiche but then has second thoughts and crosses it out. He might have linked the two artists in his mind, following a conversation with Blanche who, in his review of the Sargent exhibition in Paris in 1926, wrote of 'the great American' that he 'exuded Anglo-Parisian elegance like Helleu, his friend and fellow student at the Ecole des Beaux-Arts'. ${ }^{26}$ As a friend of both Sargent and Proust, Helleu drew their circles closer together, even though he might not have drawn their attention to their respective works nor brought them face to face with each other.

The other links that can be made between Proust and Sargent are even more speculative as they are not based on explicit references in either Proust's correspondence or in the pastiche. They suggest possible but unrecorded connections, plausible encounters in an atmosphere of shared aesthetics and social preoccupations. Although they do not offer concrete evidence that Proust and Sargent ever met, they furnish ample proof that they moved in the same circles, at the same time, and pursued the same artistic objectives. Their meeting of minds was fostered by these connections and is refracted in their work. In geometrical terms, their relationship is characterized by incidence and coincidence.

Proust and Sargent are drawn together in a coterie of musicians. They were both very close to Léon Delafosse, a pianist of modest social origin who played on his charm to secure his advancement. He was referred to as an 'angel', and Proust's friend Fernand Gregh even described him as one of the 'prettiest men' of his generation. ${ }^{27}$ It is very likely that Proust saw Sargent's portrait of Delafosse (circa 1894), as it was painted during a period during which Proust was intimate with the pianist. He says nothing of the portrait, so it is impossible to know if he noted how sensuously Sargent painted the pianist's fingers splayed out on his hip, like a fan. It is equally possible that Proust saw the two Venetian watercolours that Sargent gave to Delafosse - Along the Grand Canal (1902) and Drying Sails (1903) - gifts that reveal that Sargent considered Delafosse as more of a friend than a model. A photograph taken in summer $1899,{ }^{28}$ near Evian-les-Bains, showing Proust and Delafosse with the Prince and Princesse de Polignac, amongst others, is evidence of Proust's prolonged friendship with the musician. It seems unlikely that such close friendships would not have included conversations between Delafosse and Proust about Sargent, who was already well known by others in Proust's circle at the time. That circle included Gabriel Fauré, a friend of Proust's whose portrait was painted by Sargent in circa 1889. Again, we have no trace that Proust ever saw the portrait of the musician on whom he modelled his fictitious composer Vinteuil. We do know that Fauré protected Delafosse as the pianist was renowned for performing his music. Sargent also promoted Delafosse's talent and prowess at 
playing Fauré, as evidenced in the letter he wrote to Isabella Stewart Gardner on March 9, 1899: 'Of course Delafosse is a decadent especially in the matter of neck-ties - but he is a very intelligent little Frenchman, and a composer and excellent pianist, who is probably going over to America in a year's time, so I sent his portrait over as a forerunner.... He is the only man who has taken the trouble to study certain difficult and beautiful piano compositions by Fauré'. ${ }^{29}$

Proust introduced Delafosse to Robert de Montesquiou at about the time Sargent was painting the portrait, and the pianist quickly became the aristocrat's protégé. Delafosse apparently boasted that he was the model for Proust's character, the violinist Charles Morel..$^{30}$ Both the real and the fictitious musicians have humble family backgrounds and are dependent on prominent members of high society for recognition. The fiery relationship of Morel and the Baron de Charlus reads as a replay of some of the episodes in the equally heated Delafosse-Montesquiou relationship.

Fragmentary references to Sargent in Proust's correspondence do not provide sufficient evidence to draw firm conclusions, but they do further tighten the links between the novelist and the painter. A 'Sargent letter' is the subject of two notes Proust wrote to his lover, the composer Reynaldo Hahn, in December 1906. The first reads: 'Naturally since it's the Sargent letter you want, it's these (attached) from Isnaga and Gregh that I have found. But the one from Sargent isn't lost. I will look further for it, will find it, will send it'. ${ }^{1}{ }^{1}$ Proust quickly dispatches a follow-up: 'Do you only want that the Sargent not be lost or do you want to have it now? Because of Félicie's mania for arranging letters, one in a book, another in a journal, another under a carpet, another behind the clock, etc., it could take some time to find, unless you are pressed, in which case it will be done very quickly' ${ }^{32}$ Both notes were written from Versailles, where Hahn had visited Proust at the end of October 1906, having just returned from Venice. ${ }^{33}$ Sargent had heard Hahn perform there, as he writes to his cousin Ralph Curtis, from the Palazzo Barbaro in late September 1906: 'Hahn has been singing every night either on the water or indoors, awfully good $-{ }^{\prime} .{ }^{34}$ A possible deduction is that the missing letter was from Sargent to Hahn, requesting a performance; more specifically, it could have been related to a grand musical performance of works by StSaëns, Fauré and Hahn that the latter was to give on April 11, 1907, sponsored by Winnaretta Singer, Princesse de Polignac, and held in her salon on the Avenue Henri Martin. ${ }^{35}$

The cosmopolitan, cultural salon of American-born Winnaretta Singer epitomizes the social and aesthetic milieu of both Proust and Sargent. Her home became an international forum, with a reputation for sponsoring new musical compositions and performances. Winnaretta was heiress to the Singer Sewing Machine fortune. Sargent painted her portrait in 1889 at the time of her first marriage, to Prince Louis de SceyMontbéliard; it might have hung on the walls of her residence on avenue Henri Martin (now avenue Georges Mandel) which Proust visited. Her second marriage, to Edmond, Prince de Polignac was a contract of mutual convenience (both parties were homosexual), but also of shared interests in music and the arts. Gabriel Fauré was one of the artists 
supported by the Polignacs, and Delafosse and Hahn were both guests and performers in the salon. Winnaretta was known to seek counsel of 'three of her closest friends, Montesquiou, Sargent, and Helleu' ${ }^{36}$ for advice on the artistic development of her home. So the 'Sargent letter' could have been an inquiry relative to the April 11, 1907 concert at which Hahn performed, and which Proust attended. ${ }^{37}$ There is no record that Sargent and Proust were at any of the Singer-Polignac salon events at the same time, though it is the most likely setting for a social encounter between them. More significantly, their participation in the salon's activities means that they contributed to its artistic atmosphere: the fact that the painter and the novelist were both part of this cultural hub is a significant indication that they were immersed in the same aesthetics, which they translated into their respective works.

Another brief, enigmatic reference to Sargent in Proust's correspondence opens up further artistic interactions between Proust and Sargent. It occurs in a letter to Mrs Carl Meyer, cousin of Reynaldo Hahn and wife of a prominent Jewish financier in England. He was the president of the Board of the De Beers diamond mining company based in London, the same company that fell briefly dupe to Lemoine's hoax. Proust probably knew Mrs Meyer through Hahn and was in personal communication with her at the very time Sargent was painting Mrs Carl Meyer and her Children in 1896, when he sent her an inscribed copy of his first book, Les plaisirs et les jours [Pleasures and days $].^{38}$ Did Proust connect Sargent with Lemoine because he had seen the portrait of Mrs Meyer and her children when it was exhibited at the Exposition Universelle in Paris in 1900, where it won a Medal of Honour? We have no trace of that, but we do know that in June 1904 Proust wrote to her in London to ask if she could introduce Antoine Bibesco (a friend of his and Reynaldo's) to some artists, naming Sargent and the dramatist Sir Henry Irving. ${ }^{39}$ Why would he ask for that if he knew neither Sargent nor his work himself? Proust's own preoccupation with portraying Jews in his novel would have made him sensitive to Sargent's representation of the Meyers. The portrait triggered covert - and overt - anti-Semitic comment, and Madame Meyer's precarious perch on the canapé was caricatured in cartoons showing her sliding down, as if to suggest the social position of the Jews was unstable. ${ }^{40}$

Although we can no more than speculate where and when Proust and Sargent might have met, we can identify their shared interests and common aesthetic projects. Proust's account of the party Montesquiou hosted in 1894 indicates the extent to which their social and artistic spheres overlapped: it reads like a list of the models and friends painted by Sargent, including Dr Pozzi, Judith Gautier, and Monsieur and Madame Helleu, as well as the pianist Léon Delafosse who performed at the party. ${ }^{41}$ Proust detailed how each guest was dressed, focusing on the sartorial just as Sargent attaches importance to dress, even claiming in the case of his portrait of W. Graham Robertson (1894) that the subject of the painting is the coat the model is wearing, and not the man himself. ${ }^{42}$ Sargent's portraits of ladies of society are sumptuous depictions of elegance and luxury, where the atmosphere is created through 
his play of light on the fabrics and jewellery. What Proust has to say about the Duchess of Guermantes's art of dressing and the aura she creates through her clothes is equally applicable to Sargent:

Mme de Guermantes seemed to me to carry the art of dress to even greater heights. If I went down to see her for a moment ... and found her enclouded in the mists of a dress of grey crêpe de Chine, I accepted this appearance, which I felt to be due to complex causes and unchangeable, I let myself be swept into the atmosphere it created, like that of certain late afternoons muffled in a pearl-grey floating mist. If, on the other hand, the chosen gown was Chinese with a pattern of red and yellow flames, I saw it as a brilliant sunset; these costumes were not a trivial decoration which could have been replaced by any other, but an inescapable reality, poetic in the same way as the weather, or the light peculiar to a certain time of day. ${ }^{43}$

Passages in Proust's novel focusing on footwear might have been inspired by Sargent's portrait of Dr Pozzi, where he suggestively positions the doctor's oriental slipper peeping out from under his robe. Proust might have had the portrait in mind when he scripted the scene where the Duc de Guermantes has his wife change her shoes so that they match her long red dress. ${ }^{44}$ In La Prisonnière, the narrator is keen to dress his lover Albertine in the most elegant fashion, and asks the Duchesse de Guermantes about a pair of her shoes which he had admired, wondering if they were designed by Fortuny, like some of her tea-gowns. Their exchange reads:

But you had such pretty shoes too, are they Fortuny as well? - No. I know the ones you mean, they're gold kid that we found in London, when I was shopping with Consuelo Manchester. They're extraordinary. I could never understand how they gilded the leather, it looks like a golden skin. Just that, with a little diamond in the middle. The Duchess of Manchester is dead, sadly, but if you like I'll write to Lady Warwick or the Duchess of Marlborough to see if I can find some more like it. ${ }^{45}$

Is it just coincidence that within the space of two lines Proust names three aristocratic ladies who sat for Sargent: Consuelo Manchester, Lady Warwick and the Duchess of Marlborough? Or had he seen their portraits somewhere, and if so where? Or had an acquaintance with connections to this world such as Reynaldo Hahn or Mrs Carl Meyer - shared their knowledge with him? They are not reproduced in either Alice Meynell's volume or in T. Martin Wood's book on Sargent, which Proust might have known. ${ }^{46}$ This passage on footwear merits an informed footnote specifying that two of these English aristocrats (the Duchess of Manchester and the Duchess of Marlborough) were American born and the third - Daisy Greville, Countess of Warwick - became a socialist, indicating the extent to which British aristocracy was in mutation at the time. Proust's novel parallels Sargent's work in the way it chronicles a similar mutation in French society.

The constellation of English aristocrats, along with the explicit reference to Sargent in the pastiche and the allusions to Sargent in Proust's correspondence, stack up as evidence that Proust knew more of Sargent's work than we can prove definitively. It is equally evident that they shared aesthetic preoccupations and their ambition was to portray character and social communication. They sought to represent the passing of time and the end of an era. They broached gender issues in their works, with Proust's audacious portrayal of homosexuality in Sodome et Gomorrhe seemingly pictured in 
Figure 5. Peter Milton, In

Search of Lost Time. By permission of Peter Milton.

Sargent's numerous paintings of male nudes. They both included representations of art-in-the-making in their works, creating a kind of mirror effect of the artist at work reflected by the spectator actively creating another work of art in response. Sargent's picture of Ramón Subercaseaux in a gondola in Venice (1880) focuses on the model painting the painter while the painter paints him. As Sargent had not read Proust, he would not have known that his Pavement of St Mark's (1898) corresponds to a key passage in the novel, as Proust transforms his narrator's stumbling on the same paving stones into an experience of the mémoire involontaire. Sargent is not named in À la recherche $d u$ temps perdu but the work of Proust's fictitious painter Elstir is resonant with Sargent's themes and style. In particular, Proust might have had the portrait of Mme Gautreau in mind when he writes of Elstir copying the movement of a shoulder, the strain in a neck' ${ }^{\prime}{ }^{47}$

The intuition that Sargent and Proust inhabited the same cultural milieu is represented pictorially in a pair of black and white prints by contemporary American artist Peter Milton: Visions and Revisions (2001) and In Search of Lost Time (2006) (Figure 5). ${ }^{48}$ Milton explains that he had already started constructing his composition using Sargent's paintings when his work intersected fortuitously with Proust's. He was struck by the affinities between the artist and the novelist's works and strove to establish a graphic connection, admitting that 'fascination trumped caution', adding: 'I often suspect that coincidence is just another name for a haunting' ${ }^{49} \mathrm{He}$ positions Proust in the foreground of his composition, head bent down in reflection. The elements

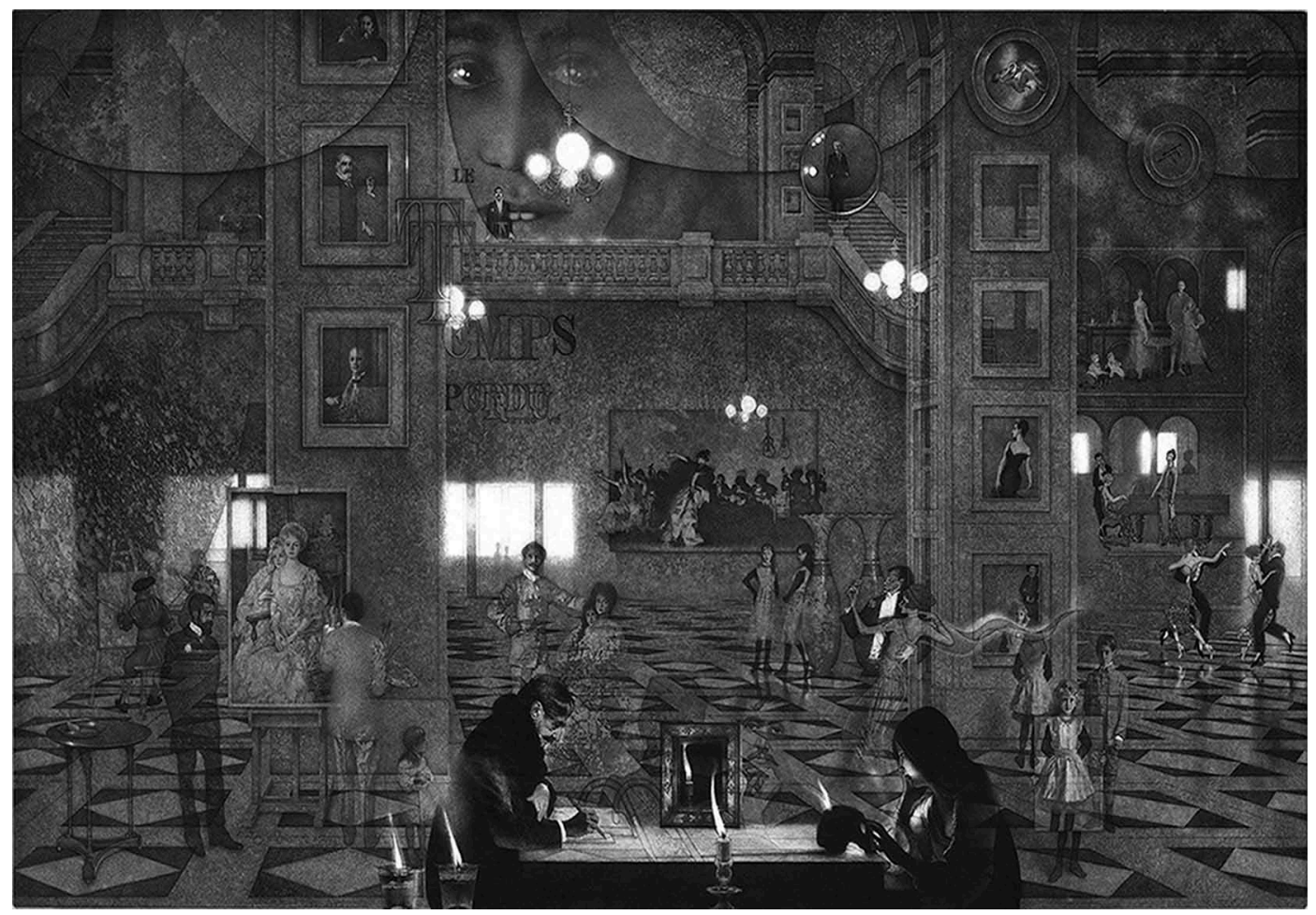


from Sargent's work arranged behind him are thus read in relation to Proust's novel: the reproductions of Sargent's portraits of Robert Louis Stevenson (whom Proust read and commented on) and Henry James on the walls evoke Proust's literary heritage just as the couples dancing across the room suggest Belle Époque gaiety. The red-haired daughter of Edward Darley Boit stares straight at us in a look as penetrating as the young Gilberte's; Milton incorporates another image of Gilberte in his composition, if we read Sargent's Mrs Fiske Warren and Her Daughter Rachel (1903) as a portrait of Odette and her daughter. The figure of the artist in his studio with Helleu evokes Elstir and his studio in Balbec. Milton consolidates the Proustian connections by inserting a photograph of Charles Haas - on whom Proust's Charles Swann is modelled - taken by Paul Nadar.

Milton said that his In Search of Lost Time was inspired by a 'haunting', a sense that Proust and Sargent were related. By positioning his ghostly figures in the same space, he creates a graphic representation of the intangible overlapping in the Proust-Sargent relationships. Milton's shadowy, black-and-white work resembles a photographic negative that has not yet been fully developed, in a suggestive picturing of the elusive mouvance in which Sargent and Proust were caught.

Emily Eells, Université Paris Nanterre Stephen Coon, Providence, Rhode Island

\section{Acknowledgement}

This work was supported in part by the CREA (Centre du recherches anglophones, Université Paris Nanterre).

\section{Disclosure statement}

No potential conflict of interest was reported by the authors.

\section{Funding}

This work was supported in part by the CREA (Centre de recherches anglophones, Université Paris Nanterre).

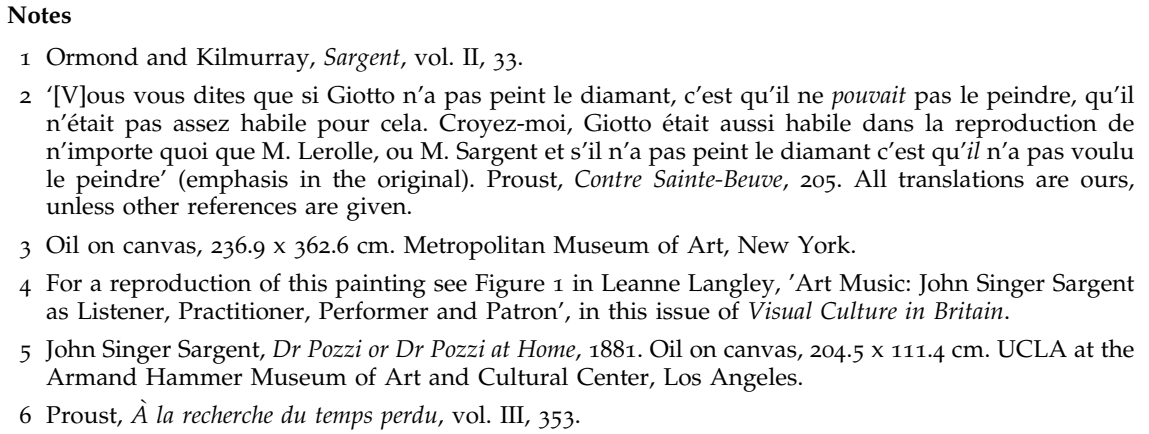
n'était pas assez habile pour cela. Croyez-moi, Giotto était aussi habile dans la reproduction de n'importe quoi que M. Lerolle, ou M. Sargent et s'il n'a pas peint le diamant c'est qu'il n'a pas voulu le peindre' (emphasis in the original). Proust, Contre Sainte-Beuve, 205. All translations are ours, unless other references are given. 
7 Joseph, 'Proust et "Docteur Dieu" ', 27-28 (emphasis in the original). Letter sent on November 6, 1914 .

8 Proust, À la recherche du temps perdu, vol. IV, 545.

9 Joseph, 'Proust et "Docteur Dieu" ', 28. Letter sent on November 13, 1914.

10 The term was coined by Charlotte Ribeyrol - see her article 'John Singer Sargent and the fin de siècle Culture of Mauve' elsewhere in this issue of Visual Cutlure in Britain.

11 See Proust, Correspondance, vol. XVII, 284: 'moi qui ai toujours connu Pozzi' (emphasis in the original).

12 They were sold by auction at the Galerie Georges Petit in Paris on June 23-24, 1919.

13 Madame Gautreau Drinking a Toast, c. 1883 . Oil on panel, 31.7 x $41 \mathrm{~cm}$. Isabelle Stewart Gardner

Museum, Boston. Incensing the Veil. Alternative titles Fumée d'ambre gris and Mauresque, 1880. Watercolour on paper. 31.1 x $19.7 \mathrm{~cm}$. Isabelle Stewart Gardner Museum, Boston. A gift from Sargent to Pozzi, it is inscribed in the lower right corner 'à Pozzi souvenir amical/John Sargent'. See Ormond and Kilmurray, Sargent, vol. IV, 305.

14 See Dorothy Moss, 'Sargent, Madame X and Baby Milbank', Burlington Magazine 143 (2001): $268-275$. 15 See 'Pictures in the New Salon', Public Opinion 36 (May 12, 1904), 592.

16 Fairbrother, Sargent: The Sensualist, 141.

17 Ibid., 22on5.

18 Ibid., $220 n 6$.

19 Proust, Correspondance, vol. V, 294. Letter written shortly after July 9, 1905 (emphasis in the original).

20 Montesquiou, 'Le Pavé Rouge', 331.

21 Ibid., 333 (emphasis in the original).

22 Ibid., 338.

23 Proust, Correspondance, vol. XVI, 399. Letter from Blanche to Proust dated September 10, 1905 (emphasis in the original).

24 See Proust, Correspondance, vol. V, 293: 'I don't know the Montecuculli Palace but thanks to that charity event which I was told you might attend, I walked around the Hôtel Béarn. It seemed to me that there were very beautiful things there'.

25 Blanche, 'Un grand américain', 337-343.

26 Ibid., 326.

27 Carter, Marcel Proust, 155.

28 The photograph belongs to the Mante-Proust Collection and is reproduced in Carter, Marcel Proust, between pages 530 and 531 .

29 Ormond and Kilmurray, Sargent, vol. II, 106.

30 See Tadié, Marcel Proust, 181. In his footnote, Tadié cites André David, Soixante-quinze années de jeunesse, Paris: André Bonne, 1974, 17-18.

31 Proust, Correspondance, vol. VI, 334.

32 Ibid., 338.

33 Ibid, 17.

34 Ormond and Kilmurray. Sargent, vol. VI, 44.

35 Kahan, Music's Modern Muse, 381.

36 www.singer-polignac.org/en/history/mansion. See the entry entitled 'La Porte Monumentale'.

37 Kahan, Music's Modern Muse, 145-146, 413.

38 That copy was on display at the exhibition John Singer Sargent's Mrs Carl Meyer and her Children, Jewish Museum, New York, September 16, 2016 - February 5, 2017. One review of the exhibition quotes the notes presenting the display which suggest that the book Mrs Meyer appears to have tossed aside in Sargent's painting 'might be the one that Proust inscribed and sent to Adèle [Meyer]'. See http:/ / www.tikkun.org/tikkundaily/2016/og/27/a-family-story-john-singer-sargents-mrs-carlmeyer-and-her-children/

39 See Proust, Correspondance, vol. IV, 165.

40 See, for example, the caricature of Mrs Carl Meyer and her Children in Punch, vol. CXII, May 8, 1897, 227. Its caption reads: 'The Perils of Steep Perspective: "Hold up, mother, it's only like the switchback!" '

41 Proust, 'Une fête littéraire à Versailles', Contre Sainte-Beuve, 360-365. First published in Le Gaulois, May 31, 1894, under the pseudonym 'Tout-Paris'.

42 'But the coat is the picture', cited in Ormond and Kilmurray, Sargent, vol. II, 87. For a reproduction of the Robertson portrait see Figure 4 in Hadrien Viraben, 'Le Pavé Rouge: Making an Example of John Singer Sargent' in this issue of Visual Culture in Britain.

43 Proust, À la recherche du temps perdu, vol. III, 542-543; Proust, Prisoner, 25.

44 See Proust, À la recherche du temps perdu, vol. II, 883-884. 
45 Proust, À la recherche du temps perdu, vol. III, 552; Proust, Prisoner, 35.

46 T. Martin Wood, Sargent, London: T. C. \& E. C. Jack, 1909.

47 Proust, À la recherche du temps perdu, vol. II, 206.

48 https://www.petermilton.com/gallerya/3ugbrjr17hnyhyuhngz95lvnsjaoao

49 https://static1.squarespace.com/static/583c833659cc68a8c3c56675/t/5908ddode4fcb524ee59db32/

1493753101993/cat129.pdf, p. 2.

\section{Works cited}

Blanche, Jacques-Émile, ‘Un grand américain' in Propos de Peintre [1926], Paris: Séguier, 2013, 325-346.

Carter, William C., Marcel Proust: A Life, New Haven and London: Yale University Press, 2000.

Fairbrother, Trevor, John Singer Sargent: The Sensualist, New Haven and London: Yale University Press, 2000.

Joseph, Lawrence, 'Marcel Proust et "Docteur Dieu": Lettres inédites à Samuel Pozzi", Bulletin Marcel Proust 51 (2001): 11-29.

Kahan, Sylvia, Music's Modern Muse: A Life of Winnaretta Singer, Princesse de Polignac, Rochester, New York: University of Rochester Press, 2003.

Meynell, Alice (introduction), The Work of John S. Sargent, London: William Heinemann, 1903.

Montesquiou, Robert de, 'Le Pavé Rouge', Les Arts de la Vie (June 1915): 329-348.

Ormond, Richard, and Elaine Kilmurray. John Singer Sargent: The Early Portraits: Complete Paintings, Volume I. New Haven and London: Yale University Press, 1998.

Ormond, Richard, and Elaine Kilmurray. John Singer Sargent: Portraits of the 189os: Complete Paintings, Volume II. New Haven and London: Yale University Press, 2002.

Ormond, Richard, and Elaine Kilmurray. John Singer Sargent: Figures and Landscapes, 1874-1882. Complete Paintings, Volume IV. New Haven and London: Yale University Press, 2006.

Ormond, Richard, and Elaine Kilmurray, John Singer Sargent: Venetian Figures and Landscapes, 1898-1913. Complete Paintings, Volume VI. New Haven and London: Yale University Press, 2009.

Proust, Marcel, À la recherche du temps perdu (4 volumes), ed. Jean-Yves Tadié. Paris: Gallimard, Bibliothèque de la Pléiade, 1987-1989.

Proust, Marcel, Contre Sainte-Beuve, eds Pierre Clarac and Yves Sandre. Paris: Gallimard, Bibliothèque de la Pléiade, 1971.

Proust, Marcel, Correspondance de Marcel Proust (21 volumes), ed. Philip Kolb. Paris: Plon, 1970-1993.

Proust, Marcel, The Prisoner, translated by Carol Clark. London: Allen Lane, 2002.

Tadié, Jean-Yves, Marcel Proust: A Life, translated by Euan Cameron. New York: Viking, 2000.

Emily Eells is professor of British literature at the University of Paris at Nanterre. Since the publication of her monograph Proust's Cup of Tea: Homoeroticism and Victorian Culture (Ashgate, 2002), she has pursued her research on Proust's interactions with artists and writers of the English-speaking world.

Stephen Coon studied comparative literature at the University of California at Irvine and at Brown University. Recently retired from a career in business strategy, he leads reading groups at the Providence Athenaeum, including the current Proust Reading Group. 